English Historical Review

(C) Oxford University Press 2019. All rights reserved.

doi:10.1093/ehr/cez291

\title{
Magazine Culture, Girlhood Communities, and Educational Reform in Late Victorian Britain*
}

In February 1878, Anastasia Cresswell placed an advertisement in Aunt Judy's Magazine:

The secretary of a small monthly manuscript magazine asks if any of our readers would like to become contributors. They must be more than fourteen years of age, and pay $2 s$ a year as subscription. Two prizes are given half-yearly, and other prizes offered every month for papers on given subjects. Rules can be had on sending a stamped and addressed envelope to Miss A. Cresswell, Lugehay House, Teignmouth. ${ }^{1}$

One young reader of Aunt Judy's Magazine, I6-year old Eva KnatchbullHugessen, was quick to respond. As she recorded in her diary, 'In the last number of "Aunt Judy" I saw a notice of a small MS magazine, so I wrote for the rules to the editor, they came today, \& I decided to join'. ${ }^{2}$

Cresswell's advertisement was one of dozens of similar notices for manuscript magazines that appeared in periodicals in mid-and late Victorian Britain. They demonstrate the desire of young people to seize new opportunities to create their own youth-centred networks of cultural exchange. Facilitated by improvements to the Victorian postal system, and using a shared periodical readership as the initial point of contact for members, circulated manuscript magazines were an extraordinary form of social authorship. ${ }^{3}$ While boys participated in the practice, ${ }^{4}$ it was a phenomenon in which girls and young women were especially active during the I870s and I880s.

There were many kinds of manuscript magazines in Victorian Britain: family productions, school magazines, and those produced by small communities such as chapels or adult education societies. Research on all this activity is still in its infancy, but this study will consider the ways in which Victorian girls appropriated the genre for their own purposes. Sometimes these ventures emerged out of existing friendship groups.

I. Aunt Judy's Magazine, vol. xvi, no. I62 (I878), p. 252.

2. Maidstone, Kent History and Library Centre, U95I/F30/3, Diary of Eva KnatchbullHugessen (Dec. I877-Apr. I879), 2I Feb. I878. In subsequent references to Knatchbull-Hugessen's diary, the archive number of each volume will be given on first citation; thereafter the reference will be 'Knatchbull-Hugessen, Diary' and the date. As the pagination of Knatchbull-Hugessen's diaries is often inaccurate, page numbers are not given.

3. For the concept of 'social authorship', see M. Ezell, Social Authorship and the Advent of Print (London, 1999).

4. See the correspondence columns of Beeton's Boy's Own Magazine; for example, that of I Mar. I868. In one issue alone of the juvenile periodical Round Robin, the correspondence page featured advertisements for four different amateur magazines, 'The Castle', 'The Vaudeville Magazine', 'The Express' and 'The Boys' Companion': Round Robin, I Mar. I872, p. 5. 
Two such manuscript magazines have come to light and are beginning to receive scholarly attention. ${ }^{5}$ These magazines are an important part of the analysis which follows. However, in a significant development, many young people, such as Anastasia Cresswell, began to use the correspondence columns of published periodicals as a means to connect with potential contributors from outside their existing circles of acquaintance. These connections enabled the production of what I will refer to as 'circulated manuscript magazines'. Such circulated manuscript magazines were apparently ubiquitous; as Cresswell's sister Beatrix noted, they were 'much in vogue'. ${ }^{6}$ Yet this was an ephemeral form of juvenile publication and extant copies of Cresswell's magazine have not yet come to light. Due to the rarity of surviving circulated manuscript magazines, the phenomenon has never been discussed, or, as far as I am aware, even noted in the British context.

Notwithstanding the disappearance of circulated manuscript magazines from the historical record, this essay will seek to establish the importance of this forgotten genre. In so doing, it will suggest that young women's circulated manuscript magazines should be understood as part of a nexus of overlapping cultural activities which 2.20 included self-directed correspondence, collaborative self-education, and girlhood sociability. This was a period of striking advancement in lifestyle and education for middle-class girls. Examining dynamic activities undertaken by teenagers and young women, such as the composition of manuscript magazines, provides us with an unparalleled opportunity to explore these developments at the grass-roots level.

The absence of surviving copies creates obvious methodological challenges. However, these are not atypical issues for historians of childhood, who are accustomed to working with textual absences

5. These are 'The Barnacle' and 'The Evergreen Chain'. The better known of these is 'The Barnacle', edited by Charlotte Yonge. Extant copies are held at Lady Margaret Hall, University of Oxford. See J. Courtney, “The Barnacle”: A Manuscript Magazine of the I86os', in C. Nelson and L. Vallone, eds., The Girl's Own: Cultural Histories of the Anglo-American Girl, I830-19I5 (Athens, GA, 1994), pp. 7I-97; and G. O’Brien Hill, 'Charlotte Yonge's "Goosedom”', Nineteenth-Century Gender Studies, viii, no. I (20I2), available at http://ncgsjournal.com/issue8I/hill.htm. Extant copies of 'The Evergreen Chain' are held at the Museum of Childhood, Edinburgh. Like 'The Barnacle', this magazine appears to have been circulated among a network of individuals with family and associational connections, rather than from an initial point of contact in a published periodical. My thanks to Lois Burke for this information. These two magazines are the subject of a forthcoming article on literary appropriation by Burke: "Meantime, It Is Quite Well to Write": Writing and Victorian Literary Culture in Girls' Manuscript Magazines', Victorian Periodicals Review (forthcoming). One further example of such a magazine has been found: 'The Miscellany' (I867-73), edited by Ellen and Daisy (Margaret) Bradley. Their father, George Grenville Bradley, was Master of Marlborough College and subsequently of University College, Oxford. Bodleian Library, MSS Don e. 35 and d. 96-IOI. 'Bird of Passage' (I88I-3), a British circulated manuscript magazine for children, is available online via the website of the Toronto Public Library at http:// www.torontopubliclibrary.ca. However, its editor was an adult and so it was rather different from the magazines considered here.

6. Exeter, Devon Heritage Centre, West Country Library Service, MSX 920/CRE, Beatrix Cresswell, 'Autobiographical Notes' [hereafter Cresswell, 'Autobiographical Notes']. 
and fragmentary archival traces. ${ }^{7}$ In this instance, while no copies of Anastasia Cresswell's manuscript magazine have come to light, through great serendipity unpublished ego-material has survived both from her sister, Beatrix, and from one of the magazine's contributors, Eva Knatchbull-Hugessen. These documents, combined with the published advertisements for this and other similar magazines, allow for a detailed consideration of the genre.

Cresswell's advertisement was typical of those of many prospective editors, and it was also in line with the entries for the eight magazine societies featured in the Directory of Girls' Societies, Clubs and Unions in $1886 .{ }^{8}$ When issuing an advertisement of this type, originators of a circulated manuscript magazine generally hoped to attract twenty or so contributors to their enterprise. The magazines were typically miscellaneous publications, featuring essays, poems, short stories, and sometimes translations. Contributors would pay an annual subscription (two shillings in the case of Cresswell's magazine), which would go towards the costs of binding and enable prizes to be given for the best submissions. Prizes were generally awarded by the contributors themselves. On receiving the latest issue, participating readers were expected to provide constructive criticism and usually to award marks, before passing that number promptly on to the next name on the register. In these ways, contributors were constructing tangible networks as they engaged in the common cause of intellectual endeavour. Many manuscript magazines must have been short-lived, but they had the capacity for considerable longevity. Indeed, some magazine editors chose to emphasise their project's durability in order to attract contributors. In I883, Alice Banks from Scarborough advertised in Aunt Judy's Magazine that her manuscript magazine was in its sixth year. ' Cresswell's 'Our Monthly Magazine' was still in operation eight years after its launch. ${ }^{10}$

The conceptualisation of the category of 'girlhood' as a distinctive life-stage for females aged from their mid-teens to their early twenties was emerging in this period." Growing numbers of publications, such as the Monthly Packet (185I-98), the Girl's Own Paper (I880-1908) and Atalanta (I88897), started to enjoy widespread appeal, targeting this newly crystallising girlhood constituency. ${ }^{12}$ In an important study, Sally Mitchell argued that a

7. K. Sánchez-Eppler, 'In the Archives of Childhood', in A.M. Duane, ed., The Children's Table: Childhood Studies and the Humanities (Athens, GA, 2013), pp. 213-37.

8. S.F.A. [Sophia Frances Anne] Caulfield, A Directory of Girls'Societies, Clubs and Unions, Conducted on Unprofessional Principles (London, 1886), pp. 69-73.

9. Aunt Judy's Magazine, new ser., ii, no. I (I883), p. v.

Io. Caulfield, Directory of Girls' Societies, p. 72.

II. H. Marland, Health and Girlhood in Britain, I874-1920 (Basingstoke, 2013), pp. 3-6.

I2. S. Walton, "Spinning the Webs": Education and Distance Learning through Charlotte Yonge's Monthly Packet', Victorian Periodicals Review, xlix (2016), pp. 278-304; K. Moruzi, Constructing Girlhood through the Periodical Press, I850-I9I5 (Aldershot, 20I2), pp. I-20; B. Rodgers, Adolescent Girlhood and Literary Culture at the Fin De Siècle: Daughters of Today (Basingstoke, 20I6), ch.I. 
Page 4 of 27 MAGAZINE CULTURES, GIRLHOOD

new culture of girlhood began to emerge during the I880s, reaching fruition in the early years of the twentieth century. It offered imaginative space for young females to reassess the options available to them in employment, education and leisure. ${ }^{13}$ Mitchell's work was based primarily on stories authored by adults in the commercial press. In contrast, this essay throws a spotlight on the role played by young females themselves in the creation of the new girls' culture of the period. In so doing, it suggests that we should think broadly of a 'magazine culture', in which amateur, manuscript and professionally printed titles supported and fed off each other. Periodicals 4.IO encouraged an active readership and also established a medium through which readers could contact potential contributors for their own ventures. The correspondence pages of these publications reveal how manuscript magazines formed part of an extensive web of cultural societies initiated by young women, including associations for reading, essay-writing, art, and language study. A desire to connect with like-minded girls, and to create networks for the circulation of one's own intellectual efforts, was an extraordinary feature of these decades, and one which pre-dates the later heyday of the 'new girl' phenomenon identified by Mitchell.

Eva Knatchbull-Hugessen, the eager reader with which this essay 4.20 began, first contributed to a manuscript magazine in I878. This year represented, as one account has put it, 'the dawn of a new era' for female education. ${ }^{14}$ It was the year when the University of London began to admit women and the Association for the Higher Education of Women in Oxford was established. The following year was also 4.25 momentous, with the opening of Somerville, Lady Margaret Hall, and the Society for Home Students (later St Anne's) in Oxford. This followed a series of reforms: girls were permitted to take Cambridge Local Examinations in 1865 (from 1870 in Oxford), and those aged over I8 could sit Cambridge Higher Local Examinations in 1869 4.30 (from 1875 in Oxford). ${ }^{15}$ These reforms have usually been analysed from the perspectives of contemporary campaigners, politicians and educational professionals. ${ }^{16}$ However, their success depended upon a generation of young females being prepared to take new, sometimes daunting steps_-something which has received little sustained analysis. 4.35 The material examined here shows how the activities of, and subjective changes experienced by, young women were a vital part of these broader educational and social developments.

I3. S. Mitchell, The New Girl: Girls' Culture in England, I880-I9I5 (New York, I995).

I4. R.D. Pope and M.G. Verbeke, 'Ladies' Educational Organizations in England, I865-85', Paedagogica Historica, xvi (1976), p. 336.

I5. For full details, see J. Roach, Public Examinations in England, I850-I900 (Cambridge, 197I), ch. 5 .

16. See Pope and Verbeke, 'Ladies' Educational Organizations'; D. Bennett, Emily Davies and the Liberation of Women (London, 1990); S. Fletcher, Feminists and Bureaucrats: A Study in the Development of Girls' Education in the Nineteenth Century (Cambridge, 1980); J.S. Pedersen, The 
COMMUNiTIES AND EDUCATIONAL REFORM Page 5 of 27

This article considers how female teenagers were active in constituting a reformed girlhood identity in mid-and late Victorian Britain. Periodical culture, through advice columns and correspondence pages, could, as Barbara Green has argued, provide 'a site for securing new identities for women'. ${ }^{17}$ Building on existing scholarship on girls' magazines, but narrowing the focus to the manuscript magazine and other educational societies advertised in these publications, the discussion here indicates the extent to which young females were seeking out opportunities for educational advancement. Moreover, examining manuscript magazines within the broader culture of girls' associational life and self-education illuminates some of the subtle metamorphoses in girlhood subjectivity which participation in such enterprises could effect.

I will begin by establishing the cultural context of the circulated manuscript magazine, before considering the wider connections between magazine culture and girls' educational reform. The central part of the article then focuses upon a single manuscript magazine, 'Our Monthly Magazine'. Its origins within the Cresswell family circle, and the Cresswell sisters' aims for it, will first be outlined. This will be followed by a detailed consideration of the impact of the magazine upon Eva Knatchbull-Hugessen. The article goes on to use Knatchbull-Hugessen as a case-study for the ways in which participation in a manuscript magazine was entwined in a broader culture of correspondence learning, girlhood sociability and associational life. Before concluding, I will consider the 'afterlives' of the 'Our Monthly Magazine' contributors, for they exemplify the complex and varied careers of these 'new women' in a period of dramatic social change for young females.

\section{I}

The phenomenon of the circulated manuscript magazine derived from a much broader participatory magazine culture. 'Multi-author texts' had antecedents in late eighteenth-century ladies' magazines, which encouraged reader engagement through correspondence columns. ${ }^{18}$ From the early Victorian period onwards, a new generation of popular magazines and family miscellanies developed such strategies further. With the advent of the penny post in I840, readers could be encouraged actively to engage with publications through correspondence pages, advice columns, and poetry and essay competitions. ${ }^{19}$ By I870, one

I7. B. Green, 'Complaints of Everyday Life: Feminist Periodical Culture and Correspondence Columns in the Woman Worker, Womenfolk and the Free Woman', Modernity Imodernity, xix (2012), pp. 46I-85, at 466.

18. M. Beetham, A Magazine of her Own? Domesticity and Desire in the Woman's Magazine, I800-I9I4 (London, 1996), pp. I9-2I.

19. C. Furlong, 'Health Advice in Popular Periodicals: Reynolds Miscellany, the Family Herald, and their Correspondence', Victorian Periodicals Review, xlix (2016), pp. 28-48; K. Blair, "Let the Nightingales Alone": Correspondence Columns, the Scottish Press, and the Making of the Working-Class Poet', Victorian Periodicals Review, xlvii (20I4), pp. I88-207; L. James, "“Now Inhale the Gas": Interactive Readership in Two Victorian Boys' Periodicals, I855-1870', Victorian Periodicals Review, xlii (2009), pp. 64-80. 
Page 6 of 27 MAGAZINE CULTURES, GIRLHOOD

publication alone, the Family Herald, was receiving about 200 letters a week. ${ }^{20}$ Furthermore, the willingness of editors to invite contributions from their readers in the form of essays and poems could blur the distinction between professional and amateur composition. ${ }^{21}$

The new generation of girls' magazines was especially keen to encourage a reciprocal relationship with its readership. One contemporary commentator on girls' reading, Edward Salmon, observed the extraordinary interest in magazine competitions, for example. He noted that a competition run by the Girl's Own 6.Io Paper, for the best 'Biographical table of famous women', elicited nearly 5,000 entries. ${ }^{22}$ These forms of active readership have been elucidated by recent scholarship. Kristine Moruzi has examined the correspondence pages of the Girl's Own Paper, showing how girls were encouraged to interact with the publication and how they 6.I5 actively shaped its debates on girlhood. ${ }^{23}$ According to Cynthia Ellen Patton, in her study of the same publication's advice columns, the greater autonomy encouraged by the new girls' culture, and the subtle lessening of parental authority, made it easier for young women to turn to other sources of advice in this way. ${ }^{24}$ Beth 6.20 Rodgers has expertly demonstrated how girls' periodicals helped to create an imagined community of young female readers, through competitions, correspondence pages and reader polls. ${ }^{25}$ The study of correspondence columns indicates that a concern with selfimprovement and education was often central to these practices of 6.25 interactive reading. ${ }^{26}$ Aunt Judy's Magazine (I866-85), the favoured reading of Anastasia Cresswell and Eva Knatchbull-Hugessen, was especially active in cultivating a relationship with its readers. Moruzi points, for example, to the editors' use of charitable appeals, in particular fundraising for Great Ormond Street Hospital for 6.30 Sick Children, to create a sense of brand loyalty to the magazine. Through printing in each issue the names of charitable donors, the magazine encouraged the development of a positive self-identity for

20. T. Gerrard, 'New Methods in the History of Reading: "Answers to Correspondents" in the Family Herald, I860-1900', Publishing History, xliii (1998), pp. 53-69.

2I. K. Ledbetter, British Victorian Women's Periodicals: Beauty, Civilisation, and Poetry (Basingstoke, 2009), ch. 4 .

22. Edward G. Salmon, 'What Girls Read', The Nineteenth Century: A Monthly Review, xx, no. II6 (I886), p. 521.

23. Moruzi, Constructing Girlhood, ch. 4.

24. C.E. Patton, “Not a Limitless Possession": Health Advice and Readers' Agency in the Girl's

Own Paper, I880-I890', Victorian Periodicals Review, xlv (20I2), pp. III-33.

25. Rodgers, Adolescent Girlhood, ch. 2. For a slightly later period, see B. Van Puymbroeck, 'Becoming a Land Girl: Reprinting Alice Meynell's "The Shepherdess" in The Landswoman', Victorian Periodicals Review, 1 (2017), pp. 398-417. See also S. Pooley, 'Children's Writing and the Popular Press in England, I876-1914', History Workshop Journal, no. 80 (2015), pp. 75-98.

26. P.J. Anderson, "Factory Girl, Apprentice and Clerk": The Readership of Mass-Market 
COMMUNITIES AND EDUCATIONAL REFORM Page 7 of 27

its readers as members of a cohesive, participatory community. ${ }^{27}$ Similarly, Caroline Sumpter has identified the ways in which the editors of the magazine (Margaret Gatty and her daughters Horatia Gatty and Juliana Ewing) cultivated a 'dialogic' relationship with their young readers through the correspondence pages. ${ }^{28}$

To date, however, little attention has been paid to the fact that consumers of Aunt Judy's Magazine, and of the other girlhood titles, were increasingly active in using correspondence columns to communicate directly with other young readers in order to form educational associations. The fact that readers had to provide their addresses to make contact with other potential participants means that many can be traced through census data. This is an approach which, as Lynne Warren has established in the case of women's magazines, provides a superb opportunity for reconstructing the 'real' identities of readers. ${ }^{29}$ Ida Meynell (b. I860) of Dawlish in Devon, for example, explained she had a 'few vacancies for contributors to a MS. Magazine. The writers must be over fourteen years of age' ${ }^{30}$ Those with more specialised interests were also sought: Miss Hicks of Roper Gate, Pontefract, advertised that she had three vacancies for 'girls under 17 years of age' for an English Essay Society; Roma Austen (born in 1859), the daughter of a Kentish magistrate, hoped for members for a 'French Essay and Translation Society'. ${ }^{31}$ Mary Pott (also b. 1859), the daughter of the local vicar in Clifton Hampden, South Oxfordshire, was looking for contributors to a 'German and French Translation Society'. ${ }^{32}$ Readers might also write in wishing to join such societies. For example, Miss B. Duff, from Elie in Fife, hoped to join an essay society for those aged I2 years and older. Adelaide Everest from Clapham wished to contribute to an amateur magazine, while 'Gipsy', clearly a less confident reader, sought 'an Essay Society whose rules are not very difficult to comply with'. ${ }^{33}$ Unearthing such girlhood readers reveals the dynamic actions undertaken by young females in order to advance their own education. In so doing, they constructed girlhood networks whose boundaries transcended the community of the adult-produced publication.

27. K. Moruzi, “'Donations Need Not Be Large to Be Acceptable”: Children, Charity, and the Great Ormond Street Hospital in Aunt Judy's Magazine, I868-1885', Victorian Periodicals Review, 1 (2017) pp. 190-2I3.

28. C. Sumpter, The Victorian Press and the Fairy Tale (Basingstoke, 2008), pp. 35-37, 62-66. Aunt Judy's Magazine was established by Ewing's mother, Margaret Gatty, in I866. When she died in I873, Juliana Ewing and her sister Horatia K.F. Gatty jointly edited the magazine until I876, at which point Ewing assumed sole editorship until I885.

29. L. Warren, "Women in Conference": Reading the Correspondence Columns in Woman, I890-19I0', in L. Brake, B. Bell and D. Finkelstein, eds., Nineteenth-Century Media and the Construction of Identities (Basingstoke, 2000), pp. I22-34.

30. Aunt Judy's Magazine, xvii, no. I58 (I879), p. 5II.

31. Aunt Judy's Magazine, xv, no. 138 (1877), p. 759.

32. Aunt Judy's Magazine, xviii, no. I62 (I880), p. 63; N. Hammond, 'The Missing Diaries of the Venerable Alfred Pott', Oxoniensia, lxx (2005), pp. 7I-8.

33. Aunt Judy's Magazine, xvi, no. 147 (I878), p. 573; xix, no. I8I (I88I), p. 443; xviii, no. I63 (I880), p. 62. Adelaide Everest's first name has been identified through census data. 


\section{Page 8 of 27 MAGAZINE CULTURES, GIRLHOOD}

From the sparse evidence available, it would appear that girls' circulated manuscript magazines and their associated activities were a largely middle-class phenomenon, or at least that this was the case with the organising editors. The Cresswell sisters were from a clerical family, as were many of the young women who used the columns of Aunt Judy's Magazine to promote their charitable and educational activities. ${ }^{34}$ The addresses of prospective editors usually suggest elite properties. For example, those seeking contributors to manuscript magazines in Aunt Judy's Magazine included Miss B. Savile of 'Heydon House' in Royston, 'Madcap May' who lived at 'Corriechoillie' in Inverness-shire, and Miss C.F. Briggs of 'Catherington House', Horndean. ${ }^{35}$ Magazine editors seem also to have expected their contributors to be familiar with elite cultural references. ${ }^{36}$ Given the resources and the level of educational attainment required to contribute to a magazine, this is unsurprising. In addition, middle-class Victorian children were widely acculturated to magazine writing, with family manuscript magazines supplying a common form of domestic entertainment. The Gatty family who edited Aunt Judy's Magazine were themselves participants in this tradition, producing a number of domestic manuscript magazines. ${ }^{37}$

To date, attention has focused upon the family magazines produced by the likes of the Brontës, the children of Charles Dickens, Mary Humphrey Ward, C.S. Lewis, Virginia Woolf and siblings, and Robert Louis Stevenson. ${ }^{38}$ However, libraries and provincial archives are rich repositories of family magazines, most of which still await scrutiny, 8.25 and which testify to widespread practice of domestic magazine composition. ${ }^{39}$ Private printing presses enjoyed some popularity in the Victorian period and on occasion such magazines were printed. One of the earliest self-printed juvenile productions appears to have

34. See, for example, Aunt Judy's Magazine, xvi, no. I40 (I878), p. I24; new ser., i, no. 5 (I882), p. 315; xvii, no. 162 (1879), p. 758 . The publication was designed to be more diverting than the earnest Monthly Packet. It supposed a family-centred readership, whereas the Monthly Packet explicitly targeted women aged is to 25 years. However, Aunt Judy's Magazine was popular with this demographic, with correspondence pages full of advertisements sent in by young and teenaged women. S. Drain, 'Family Matters: Margaret Gatty and Aunt Judy's Magazine', Publishing History, lxi (2007), pp. 5-45; Sumpter, Victorian Press, p. 36.

8.35 35. Aunt Judy's Magazine, xv, no. I36 (I877); xvii, no. I62 (I879), p. 753; xix, no. I83 (I88I), p. 574; new ser., i, no. II (I882), p. 7 OI.

36. See below, at nn. 65, 67 .

37. Sumpter, Victorian Press, p. 63.

38. C. Alexander, 'Play and Apprenticeship: The Culture of Family Magazines', in ead. and J. McMaster, eds., The Child Writer from Austen to Woolf (Cambridge, 2005), pp. 3I-50; A. Bunyan, 'The Children's Progress: Late Nineteenth-Century Children's Culture, the Stephen 8.40 Juvenilia, and Virginia Woolf's Argument with her Past' (Univ. of Oxford D.Phil. thesis, 20oI), ch. 4 .

39. See, for example, O. Bell and A. Bell, 'Children's Manuscript Magazines in the Bodleian Library', in G. Avery and J. Briggs, eds., Children and their Books: A Celebration of the Work of Iona and Peter Opie (Oxford, 1989), pp. 399-412; Bunyan, 'Children's Progress', ch. 4. Further indicative examples include Stratford-upon-Avon, Shakespeare Birthplace Trust, DR 67I/528-31, Leigh family, 'Stoneleigh Holiday Magazine'; Stafford, Staffordshire Record Office, D 4998/B/4/2, 
been The Bouquet, produced by a circle of aristocratic female teenagers in the early I850s. ${ }^{40}$ As this last example suggests, children were also active in creating their own publications independently of the family. Catherine Sloan has recently demonstrated that scholars have, for example, underestimated the extraordinary breadth of the genre of the school magazine, which appeared in manuscript, privately printed and published forms. ${ }^{41}$ Involvement with the school magazine was a tradition which persisted into higher education and became woven into collegiate sociability. ${ }^{42}$

From the extant evidence available, it would appear that girls' circulated manuscript magazines may have had particular similarities to the magazines commonly produced by self-improvement societies, especially those connected to church or chapel groups for the young. ${ }^{43}$ Family magazines served primarily leisure and entertainment purposes, often relying upon knowing allusions and family jokes. ${ }^{44}$ Girlhood magazines, by contrast, arose from the collaborative culture of selfeducation promoted by printed publications, and contributors would often not be known to one another. In the first study of its kind, Laura Weiss has considered the manuscript magazines produced by a Glaswegian male literary society, demonstrating the richness of the genre for understanding the culture of Victorian self-improvement. ${ }^{45}$ As Weiss explains, the magazines 'consolidate[d] a diverse set of readers from different social backgrounds into a reading community with a collective identity. ${ }^{46}$ So too in the teenage circulated magazines focused upon here, where the construction of a collective community identity-one which shared a commitment to self-improvementappears to have been at the heart of participants' aspirations.

40. The Bouquet, culled from Marylebone Gardens (London, I85I-5).

4I. C. Sloan, "'Periodicals of an Objectionable Character": Peers and Periodicals at Croydon Friends' School, I826-1875', Victorian Periodicals Review, 1 (2017), pp. 769-86.

42. L.J. Lamberton, "AA Revelation and a Delight”: Nineteenth-Century Cambridge Women, Academic Collaboration, and the Cultural Work of Extracurricular Writing', College Composition and Communication, 1xv (20I4), pp. 560-87; A. Hopkinson, preface to A Selection of Verses from the Manchester University Magazine, I868-19I2 (Manchester, 1913); H. McLachlan, 'Sport and Recreation in Nonconformist Academies', in his Essays and Addresses (Manchester, 1950), p. 209. 43. For example, Brentford Mechanics Institution: The City of London Magazine (London, I843), p. I27; Bankers' Magazine, associated with John Sparks Dalton's mutual instruction society in London: 'Memoir of the Late Mr. J. S. Dalton', Bankers' Magazine, xiii, Apr. I853, pp. 24I-7. See, for its lengthy advice, 'On Manuscript Magazines', The British Controversialist and Literary Magazine, no. 2 (I87I), pp. I45-9. By 1858 the Amateur's Magazine had started publication, followed by the foundation of the Amateur Authors' Association in I869: 'Looks into Books', Fun, 9 Jan. I869, p. I83. In contrast to the United States, where there is considerable scholarship on such developments, British literary historians are yet to fully explore this form of authorship, save for the early twentieth century. See C. Hilliard, To Exercise Our Talents: The Democratisation of Writing in Britain (Cambridge, MA, 2006).

44. Alexander, 'Play and Apprenticeship'; Bunyan, 'Children's Progress', ch. 4.

45. L. Weiss, 'The Manuscript Magazines of the Wellpark Free Church Young Men's Literary Society', in P.R. Rooney and A. Gasperini, eds., Media and Print Culture Consumption in Igth Century Britain: The Victorian Reading Experience (London, 2016), pp. 53-74.

46. Weiss, 'Manuscript Magazines', p. 67. 
Crucially, participation in magazine culture in this period had the potential to contribute in decisive ways to the broader project of educational reform. While some of the pioneering girls' schools established in the I860s and I870s tutored their pupils for the new local examinations, and many girls received strong familial support, numerous young women prepared for examinations on their own initiative. ${ }^{47}$ It has been estimated that a third or more of female students at Oxbridge colleges in the I88os had not attended school. ${ }^{48}$ For those young women seeking to take advantage of the new educational opportunities of the I870s and I88os, identifying a network of support could be crucial.

Girls' magazines constituted an important forum for information about the reforms to female education and encouraged in multiple ways strategies of self-education which could function as preparation for advanced study. As Kristine Moruzi has established, multiple and contradictory positions were articulated. Atalanta, for example, one of the most progressive titles, often reiterated traditional gender roles. ${ }^{49}$ Yet even the more conservative Monthly Packet was, by the midI870s, urging readers to take advantage of the new local examinations, assuring them of the ease and propriety of arrangements, and giving detailed advice for taking the local or higher examinations. ${ }^{50}$ The Girl's Own Paper published many supportive discussions of female higher education, including comprehensive instructions on the syllabus and application procedure for the local Cambridge examinations, as well as study tips. ${ }^{51}$ When the periodical published an article querying the advisability of female higher education, it met with a stinging rebuke from a I4-year old correspondent, Bertha Mary Jenkinson. ${ }^{52}$ The episode affirms Moruzi's important argument that girl readers, in their Educating Women: Schooling and Identity in England and France, I800-1867 (Oxford, 2007), pp. 5I-6. For the diversity of familial attitudes towards female education see D. Gorham, The Victorian Girl and the Feminine Ideal (London, I982), ch. 8.

48. J. Howarth, 'Public Schools, Safety-Nets and Educational Ladders: The Classification of Girls' Secondary Schools, I880-19I4', Oxford Review of Education, xi (1985), p. 62.

49. Moruzi, Constructing Girlhood, ch. 5 .

50. Walton, 'Spinning the Webs', pp. 280-82; 'A Letter to Candidates for the Local Examination, Part I', Monthly Packet, Jan. I877, pp. I8I-8; 'A Letter to Candidates for the Local Examination, Part II', Monthly Packet, Apr. I877, p. 37; 'Elementary Examinations for Girls', Monthly Packet, Sept. 1867, pp. 299-300.

51. 'Our Own Colleges', Girl's Own Paper, no. 32, 7 Aug. 188I, pp. 502-3; 'Work For All', Girl's Own Paper, I3 Oct. I883, pp. 25-7; 'The Learned Ladies of Bologna', Girl's Own Paper, no. I0, 6 Mar. I880, pp.I47-9; 'Examinations and How to Prepare for Them', Girl's Own Paper, no. 66, 2 Apr. I88I, pp. 425-6.

52. M.P.S., 'The Disadvantages of Higher Education', Girl's Own Paper, no. I22, I8 Feb. I882, I0.45 I0.46 p. 333; letter to editor from Bertha Mary Jenkinson, Girl's Own Paper, no. II9, 8 Apr. I882, p. 444.
}

47. C. Dyhouse, Girls Growing Up in Late Victorian and Edwardian England (London, 198I), p. 45. For further discussion of self-education in the careers of educators see C. de Bellaigue, 
COMMUNITIES AND EDUCATIONAL REFORM Page II of 27

interaction with magazines, were active in constituting, and contesting, contemporary models of girlhood. ${ }^{53}$

Certainly it would appear that girls' relationships with periodicals could provide a stimulus for individuals wishing to take advantage of the new educational routes. The children's writer and suffragette Evelyn Sharp participated in the 'Atalanta Scholarship and Reading Union' in her late teens, winning a prize in I888. Subsequently, as her biographer notes, she 'took refuge in studying - and passing - the Cambridge Higher Local Examination in History'. ${ }^{54}$ Jean Roberts, who achieved a place at Girton in 1883 , later recalled the encouragement she had felt on contributing to, and winning, prize competitions in the Monthly Packet. ${ }^{55}$

Involvement in manuscript magazines was often interwoven in such trajectories. For example, manuscript magazines could play a role in enabling young women to cultivate the necessary skills for examinations or college entrance. Prior to her more formal education at Queen's College, the novelist Lily Spender wrote for a manuscript magazine she organised with her friends. ${ }^{56}$ Molly Hughes and her friend Winnie Heath attended a girls' private school in North London, where they felt insufficiently stretched. In I88I, when Molly was I5, they set about investigating a variety of historical, literary and scientific themes which they compiled into a 'joint magazine'. With the encouragement of Molly's older brothers, and against the advice of their school, they decided that together they would enter for the senior Oxford Local Examinations, carefully researching the syllabus together. ${ }^{57}$ The Luard sisters, from an Essex clerical family, were actively involved in magazine culture in a variety of ways. Annette, Clara Georgina, Lucy, Evelyn and Rose were all members of the Humane Society, an organisation run by the children's magazine Little Folks. ${ }^{58}$ They subsequently produced a manuscript magazine with friends, 'The Societies' (a title which testifies to the prominence of associational life in these endeavours). ${ }^{59}$ Rose and Clara Georgina went on to study at Lady Margaret Hall, Oxford, and, on graduating, the latter wrote a passionate defence of female higher education in the girls' periodical Atalanta. ${ }^{60}$ These various enterprises illustrate the interconnecting relationships between juvenile sociability, female education and magazine culture.

53. Moruzi, Constructing Girlhood.

54. A. John, Evelyn Sharp: Rebel Woman, I869-I955 (Manchester, 2009), pp. II-I2.

55. Walton, 'Spinning the Webs', p. 278.

56. See E.I. Carlyle, 'Spender [née Headland], Lily [Known as Mrs. John Kent Spender] (I835I895)', Oxford Dictionary of National Biography, available online at http://www.oxforddnb.com/ view/article/26I4I (accessed I3 Aug. 2018).

57. M.V. Hughes, A London Family, I870-1900 (I946; London, I98I, pp. I48-50.

58. Little Folks, I July I882, p. 53.

59. Chelmsford, Essex Record Office, D/DLu 5I/2, Luard family archive, 'The Societies'.

6o. 'The Brown Owl', Atalanta, no. 36, I Sept. I890, p. 767. For the Luards' subsequent careers in female education, see M. Yamaguchi, Daughters of the Anglican Clergy: Religion, Gender and Identity in Victorian England (Basingstoke, 2014), pp. II9, 26I. 
These themes can be pursued further by exploring in depth the particular circulated manuscript magazine with which this article began: 'Our Monthly Magazine'. Anastasia ('Stasia') Cresswell was 23 years old when she launched the title. Her younger sister, Beatrix, aged I6, was also closely involved. Anastasia and Beatrix's father, the Reverend Richard Cresswell, was a High Church Anglican curate and private tutor. While one of their older siblings, Richard (b. I848), followed his father into the church, ${ }^{61}$ Anastasia and Beatrix had a role model of empowered womanhood in the figure of their elder sister, Christiana (Chrissy, b. I849). Chrissy had left home in I875 to seek employment in London in the creative arts. As Beatrix recalled in her autobiographical notes, this was considered 'a new departure at that date ... As something rather "fast" and shocking'. ${ }^{62}$

The origins of 'Our Monthly Magazine' and the sisters' aspirations for it reveal much about the fraught relationships which could exist between adult and youth cultures. Beatrix had already been contributing to an amateur magazine, but was unhappy with its quality. The sisters I2.20 were encouraged to launch their own magazine by a close family friend, Dottie Elliott, who had metropolitan literary connections. ${ }^{63}$ But it seems likely that further, girl-centred influences were also at play, in the sisters' awareness of 'The Barnacle' magazine. 'The Barnacle' (I859-7I) was an enterprise instigated by the prolific High Church author, Charlotte Yonge. Yonge styled herself as 'Mother Goose' to a network of (largely Tractarian) younger friends and acquaintances, the 'Gosling Society'. Participants, writing under pseudonyms, pasted their miscellaneous stories, essays, poems and translations into a volume which they then posted on to the next contributor on the address list. ${ }^{64}$ Contributions I2.30 were diverse in style and subject, but broadly reflected middle-class girls' education, with a predominance of material on history (often on highly focused subjects, such as 'The Marriage of Queen Hedwiga'), translations, music (one contributor writing on the 'Lives of Celebrated Musicians', for example), and art (a number of pieces were beautifully illustrated, such as an article on mediaeval illuminations). ${ }^{65}$

The Cresswells, as a High Church Devonshire family, were situated within precisely the environment from which a number

6I. P. Hodge, The Cresswells of Winchmore Hill: A Gifted Victorian Family (Southgate, 1999), pp. $45-6$.

62. Cresswell, 'Autobiographical Notes'. For Christiana Cresswell, see M. Quirk, 'Stitching Professionalism: Female-Run Embroidery Agencies and the Provision of Artistic Work for Women, 1870-1900', Journal of Victorian Culture, xxi (2016), p. 197.

63. Dottie Elliott's husband John wrote for literary publications and her brother, George, was the editor of The Globe: Cresswell, 'Autobiographical Notes'.

64. Courtney, 'The Barnacle'; O'Brien Hill, 'Charlotte Yonge's "Goosedom”'.

65. These examples are taken from 'The Barnacle', ii (I863), and vi (1865). See Courtney, 'The Barnacle', for a full discussion of the magazine's contents. 
COMMUNiTIES AND EDUCATIONAL REFORM Page I3 of 27

of the contributors to Yonge's magazine came, and they had many personal connections with the Barnacle network. ${ }^{66}$ 'Our Monthly Magazine' had much in common with 'The Barnacle', especially its topical spread-it featured essays on music, travel and history, and translations, as well as fiction. Its cultural allusions suggest a similarly middle-class constituency-on one occasion a prize was offered for the best-executed copy of John Everett Millais's painting, 'Mariana in the Moated Grange'. ${ }^{67}$ However, the themes set for the monthly prize essays suggest that the intellectual level expected may have been less high than that of 'The Barnacle', including, for example, 'Out-of-Door Amusements' and 'Anecdotes of Animals' (Beatrix Cresswell wrote an essay on the family's tortoiseshell cats). ${ }^{68}$ A further difference was that, like other circulated manuscript magazines, it had a more democratic structure. Whereas Yonge dispensed criticism in 'The Barnacle', in 'Our Monthly Magazine' all participants were expected to offer feedback on the others' submissions.

The Cresswell sisters received support for their literary activities from their family, with their father occasionally assisting them with their own contributions. ${ }^{69}$ However, they were keen to place strict limits on such involvement. When they set a competition in the magazine for the best French-language essay, they asked Beatrix's French governess to be the judge. Beatrix was outraged that the governess then took it upon herself to correct her own entry and insist that she rewrite it. 'I was furious,' she later recalled; 'I asserted that I had written the essay for the competition to amuse myself, and that I would not do it-finally I took the essay, tore it in four pieces, and threw it in her face! Then there was a storm' ${ }^{70}$ As this episode indicates, manuscript magazines were born out of a familiarity with wider adult cultures of writing and production, but their raison d'être was to provide independent avenues of expression for young women.

No extant copies of 'Our Monthly Magazine' have been found, but the diaries of Eva Knatchbull-Hugessen (I86I-95), one of its contributors, provide an unparalleled source for exploring the nature and significance

66. The Cresswells' closest family friends were the Reverend John Hext, vicar of Kingsteignton, and his family. One 'Barnacle' contributor, Lilian Mitchell (b. 1847) had lived with the Hexts since being orphaned at the age of 9. She married Hext's eldest son in 1874. Two other 'Barnacle' contributors, Anne Elizabeth Mary and Helen Beatrice Morshead (later author of The History of the Universities' Mission to Central Africa [London, 1905]), lived in Salcombe Regis where Richard Cresswell had held a curacy.

67. Knatchbull-Hugessen Diary, 29 May 1878.

68. Knatchbull-Hugessen Diary, is July and 30 Dec. 1878.

69. Devon Heritage Centre, 4686 M/F.3I, diary of Richard Cresswell, 7 June i878. Cresswell, 'Autobiographical Notes'. 
Page I4 of 27 MAGAZINE CULTURES, GIRLHOOD

of such a project. Knatchbull-Hugessen hailed from a minor aristocratic family which prided itself on its literary pursuits. Brought up in Smeeth, Kent, the third of four children, she was the great-great-niece of Jane Austen - a heritage eagerly embraced by family members. Her father, Edward (a Liberal cabinet minister who became Lord Brabourne in I880), had been the first to publish Austen's letters. He himself also enjoyed modest success as a writer of children's stories. ${ }^{71}$ Eva Knatchbull-Hugessen was a teenager with huge cultural opportunities. During the period in which she wrote for the magazine, she enjoyed a range of leisure pursuits, such as seeing plays in the West End, visiting art galleries and attending debates in the House of Commons. She was a voracious reader, and her wider family often lent or gave her books, or provided her with money to treat herself in London bookshops. She had a warm relationship with her German governess, and also had tutors in music and art. Knatchbull-Hugessen's brothers attended Eton College, but she was closely involved in their education, assisting regularly in school preparation in the case of her younger brother Cecil, and with army entrance exams in the case of the oldest child, Edward ('Ned'). She appears to have done this willingly and with a sense of I4.20 pride. Nonetheless, it is clear that in I878 Knatchbull-Hugessen was beginning to seek avenues for her own intellectual expression. Her father was a dominant paternal presence who, while encouraging of his daughters' intellectual activities, held conservative views on the position of women. For example, he spoke at length against female suffrage in I4.25 Parliament in I872, declaring he wished to 'shield' women from life's 'harder and sterner duties'. ${ }^{72}$ Two years later, he published a collection of children's stories which included 'The Pig Faced Queen'—a crude satire on women's public roles. ${ }^{73}$ Yet by 1883 Eva Knatchbull-Hugessen had taken the Cambridge Higher Examinations and, despite mocking comments from her father about female colleges, had embarked on study at Newnham College, Cambridge. ${ }^{74}$

By examining the years in which she was involved with the manuscript magazine, it is possible to plot some of the small but significant shifts in consciousness which led to these decisions. ${ }^{75}$ Lynne

7I. M. Wilson, Eva: An Aspiring Victorian (Tonbridge, 2008); M. Wilson, A Kent GirlGraduate (Tonbridge, 1994); C. Harman, Jane's Fame: How Jane Austen Conquered the World (Edinburgh, 2009), pp. I5I-3; J. Zipes, Victorian Fairy Tales: The Revolt of the Fairies and Elves (New York, I987), pp. I48-9.

72. Hansard, Parliamentary Debates, 3rd ser., I May I872, vol. 2II, cols. 46-54.

73. For further discussion of Edward Knatchbull-Hugessen's patriarchal attitudes, see K. Gleadle, 'Silence, Dissent and Affective Relations in the Juvenile Diaries of Eva KnatchbullHugessen (I86I-95)', I9: Interdisciplinary Studies in the Long Nineteenth Century, no. 27 (2018), available at https://www.I9.bbk.ac.uk/articles/I0.I6995/ntn.808/.

74. Kent History and Library Centre, U951.F.30.5, Knatchbull-Hugessen Diary (Jan. I883June I884), 9 July I883.

75. Knatchbull-Hugessen began contributing to the magazine in February 1878. She appears 
COMMUNiTIES AND EDUCATIONAL REFORM Page I5 of 27

Warren has explored the ongoing impact upon identity-formation of adult women's contributions to nineteenth-century correspondence columns, especially when readers 'transcended the textual community to come into actual contact with each other' ${ }^{76}$ It is likely that this was yet more intense when the magazine in question was run by the individuals themselves, as in the case of a manuscript magazine. Knatchbull-Hugessen's diaries allow us to explore this process in depth, contributing significantly to our understanding of girlhood subjectivities in this critical period of educational reform.

Analysing girls' diaries is an intricate procedure. The KnatchbullHugessen family was typical in its elaborate practices of journalkeeping, the fruits of which were often circulated or shared between family members. Such practices meant that girls rarely voiced dissension or rebellion in overt ways. Rather, as Jane Hunter has observed in her insightful analysis of nineteenth-century American girls' diaries, journals furnished 'routes of mediation'-'surrogate battlefields upon which girls struggled to blend family expectation with personal impulse'. ${ }^{77}$ For example, Eva was studying Latin in 1878 , with the help of her brother Cecil. Her wider family were aware of this (indeed she tutored her younger cousin, Wilfred), but in her diary she recorded her Latin studies in a secret code. ${ }^{78}$ That Eva recorded a well-known fact in code seems to suggest a desire to establish a small, private space of her own in which to reflect on an intellectual agenda independently of her family.

Knatchbull-Hugessen's interest in participating in a girlhood manuscript community speaks to these barely articulated facets of her interiority. Educated by a governess, usually alongside her older, more conventional sister, Kate, there are indications that KnatchbullHugessen was keen to connect with other girls. Knatchbull-Hugessen normally socialised with close family networks, local clergy, or elite parliamentary connections. She was alert to the breadth of intellectual opportunities to which she was exposed, and her place as a member of a parliamentary and literary family was key to her self-identity. However, her diaries suggest an increased awareness of, and interest in, other girlhood experiences during this period. Beth Rodgers has elaborated upon the ways in which the cultural discourse of 'girlhood' was conceptualised as a pan-class phenomenon. ${ }^{79}$ When staying with her maternal grandparents in St Albans, where her grandfather was vicar of St Stephen's church, she frequently sought out the company of

76. Warren, 'Women in Conference', p. I23.

77. J.H. Hunter, 'Inscribing the Self in the Heart of the Family: Diaries and Girlhood in LateVictorian America', American Quarterly, xliv (I992), pp. 5I-8I, quotation at 59.

78. This paragraph draws upon the following diaries of Eva Knatchbull-Hugessen: Kent Archives and Local History Centre, U951/Cir6 (Jan. I873-Apr. I876); U95I/F30/I-5 (I873-83). My thanks to Colin Rogerson for deciphering the code. For examples of the use of code, see Knatchbull-Hugessen Diary, 23 Jan., I4 Apr., I6 Apr., 2 May, I2 May, 20 May and 25 May I878. 79. Rogers, Adolescent Girlhood, ch. 2. 
Page i6 of 27 MAGAZINE CULTURES, GIRLHOOD

a group of girls from a small school run by a Miss Ann Lewis. ${ }^{80}$ She was also quick to document the variety of educational backgrounds of other girls she encountered socially, evincing surprise at the 'different ways in which girls are brought up', and expressing shock at the circumscribed I6.5 syllabus followed by some. ${ }^{81}$ But she was also beginning to encounter teenage girls with greater aspirations. On meeting a Miss Ford later in 1878, she seemed impressed that she was 'a clever faced rather pretty girl who is at Cheltenham College \& goes in for high [sic] education'. ${ }^{82}$ While Eva's identity remained rooted in a privileged social location, a heightened consciousness of girlhood was emerging.

Writing for the manuscript magazine was in some ways a response to these new sensitivities, but it also further stimulated them. Impatiently awaiting the arrival of the next issue of the manuscript magazine, and reading and judging the other submissions, are recurrent themes of I6.I5 Knatchbull-Hugessen's diary. The vigour of her interaction with it was especially high during periods when she was quite isolated at home in the small village of Smeeth (as opposed to visiting extended family or staying in London). As she recorded on i8 October, 'I was copying my two papers at every spare moment all day', and on 17 November,

I6.20 'I wrote as I did at every spare moment all today'. ${ }^{83}$ The intensity with which Knatchbull-Hugessen approached her magazine contributions was matched by other contributors. As Jane Ellen Panton recalled, 'in my strenuous youth I wrote regularly month after month and week after week for a MS. Magazine which we got up between twelve criticising members and a certain number of outsiders, ${ }^{84}$

Despite her rich and varied cultural life, Knatchbull-Hugessen sometimes felt under-stretched and the magazine gave her a structured occupation. Writing for these magazines could also introduce members to unfamiliar intellectual activities. These included the composition I6.30 of essays, something which Knatchbull-Hugessen had not attempted before and initially found difficult. ${ }^{85}$ It encouraged her to attempt new topics, such as an essay on music which she began in October I878, using the Cornhill Magazine as a research resource. ${ }^{86}$ In addition to a variety of essays, Knatchbull-Hugessen was to send in six stories as well I6.35 as poetry.

In addition to these direct educational benefits, 'Our Monthly Magazine' provided a forum in which a contributor's strengths and weaknesses were assessed alongside those of other teenaged girls and young women as part of an egalitarian community. KnatchbullHugessen followed the family practice of reading her stories aloud

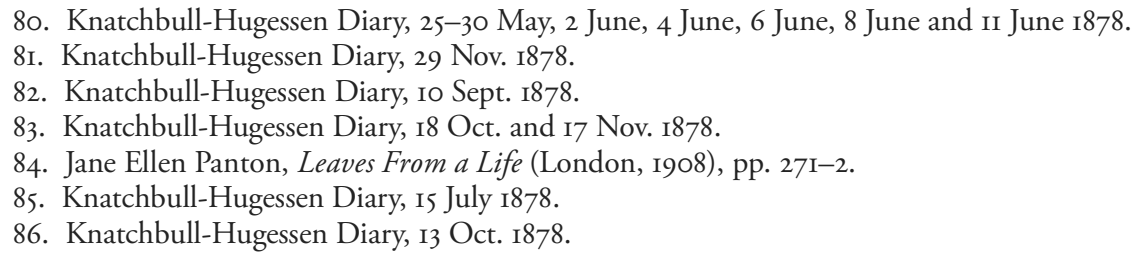


within the domestic setting (as her father frequently did with his work), but her family tended to be an uncritically supportive audience and she seems to have valued the more objective feedback she received from the magazine. ${ }^{87}$ In published magazines, editors often assumed an air of critical superiority over their amateur contributors in ways which could 'diminish the power of the reader'. ${ }^{88}$ In contrast, the democratic structure of manuscript magazine criticism was evidently welcomed by many. As Beatrix Cresswell remembered, the advantage of writing for this magazine were that 'My talents were benefited by competition with other girl writers who were quite as able, if not better than myself' ${ }^{89}$ Knatchbull-Hugessen recorded fellow contributors' assessments with seeming equanimity. Her observation, 'I only got 5 marks for the first of the "Family Failing" which was too spun out', is indicative. ${ }^{90}$ The experience led her to be more reflective about her compositions. As she wrote on 6 June, for example, 'My poem about Londonderry, has, I find on reading it over, contracted an unpleasant habit of varying considerably in its metre in different places, \& will not do, I am afraid'. ${ }^{11}$ Eva was evidently thrilled when her biography of her literary forebear, Jane Austen, won the monthly prize. '[W] hen I got home, I found a letter from my editor Miss Cresswell, informing me that I'd won the prize with the biography and enclosing 2.6 (my prize) and a certificate of my having obtained it'. ${ }^{92}$ Note the proud use of the personal pronoun here: 'my editor'. Receiving intellectual validation from her own association of like-minded young women was evidently empowering. It had the potential to contribute to new personal aspirations, as well as enhancing a sense of connection to a wider girlhood community.

The responsibility of acting as a critic to fellow contributors produced some telling subjective shifts in the narrative voice articulated in Knatchbull-Hugessen's diary. When she received the first copy of this amateur magazine, her response was refracted through the dynamics of a patriarchal family structure, for the family gathered around while her father read its contents to them. During this early stage, Eva praised a couple of the stories but was scathing about many contributions. Perhaps this was a defensive reaction, relating to her consciousness of what other family members might have thought. For example, she complained, "Belgium" is a very poor description of Brussels, "Won't you tell me why Robin?" a defective love story told in letters and in a very bad hand too. "After dark the dawn", by "Lorna Doone" contains

87. See, for example, Knatchbull-Hugessen Diary, I4 June I878.

88. Warren, 'Women in Conference', p. I3I.

89. Cresswell, 'Autobiographical Notes'.

90. Knatchbull-Hugessen Diary, 29 May 1878.

9I. Knatchbull-Hugessen Diary, 6 June I878.

92. Knatchbull-Hugessen Diary, 3 Sept. I878. 
Page i8 of 27 MAGAZINE CULTURES, GIRLHOOD

some flagrant mistakes in spelling, and moreover is evidently ended up in a hurry'. ${ }^{93}$

However, after she began to receive positive feedback for her own contributions, Knatchbull-Hugessen's tone began to change. As the months progressed, she became increasingly positive about the other contributions. Rather than positioning herself at the standpoint of elite literary authority, it would appear that she now felt a sense of camaraderie with this new writing community. She could still be acerbic about some of the submissions, and to some extent this was typical of I8.IO her pointed diary style, but she now more frequently supported with generosity the other contributions. '[A]s to the prize subject "Anecdotes of animals", she wrote on one occasion, "I had 5 marks and "Nancy Lee", who wrote a description of a race of tortoiseshell cats belonging to her family, 6 . Her paper was certainly better than the others, so I had I8.I5 to give it my mark, thus making her 7 and most likely destroying any chance of the prize for me' ${ }^{94}$ Although Knatchbull-Hugessen, as we have seen, eventually won a prize for the biography competition, she had been sobered by the excellence of a rival contribution, on Socrates: 'it has Greek quotations \& all sorts of things'. ${ }^{95}$

I8.20 An awareness of the strides other young women were making in the classics stayed in Knatchbull-Hugessen's mind. Later she recorded being seated at a dinner next to one Nelly Jemmett, who attended a school in Wimbledon, and 'had no time for German [which KnatchbullHugessen was studying], because she learned Latin, she has been learning I8.25 it for about 4 years, and is reading Virgil which excited my envy'. ${ }^{96}$ The following month, Knatchbull-Hugessen found the confidence to plead with her mother that she might receive professional tuition in Latin during their three-month stay in London. Her mother finally relented, and by the end of the month Eva too was studying Virgil. I8.30 Girls' sociability could be a crucial factor in stimulating educational aspirations.

Contributing to a magazine, whether manuscript or printed, could also facilitate girls' independent sociability. ${ }^{97}$ As Beatrix Cresswell later recalled, 'Some twenty girls from I5 to 25 contributed, and the effort proved a great I8.35 success. We made some pleasant and lasting friendships through it'. The Cresswell sisters were the only participants from Devon, but were active in cultivating relationships with contributors further afield. ${ }^{98}$ Certainly this was the case with Knatchbull-Hugessen. After contributing to the magazine for more than a year, she made arrangements to meet Anastasia I8.40 Cresswell, with whom she had struck up a correspondence, while the 
COMMUNITIES AND EDUCATIONAL REFORM Page ig of 27

two were in London. Knatchbull-Hugessen recorded enthusiastically, 'We soon got on well, \& chatted away about the magazine'. It was clearly enthralling for her to hear more about the other contributors, "To my surprise I heard that she was "Daniel Deronda"! Her sister, "Nancy Lee", the Greek scholar who wrote the life of Socrates which ran my biography of Jane Austen so close. They are evidently a clever energetic family, the girls taught by the father'. Knatchbull-Hugessen made some assumptions about their status and lifestyle, writing that they had 'not lived very much away from Teignmouth or had many opportunities of seeing things \& people'. ${ }^{9}$ However, she appears to have been conscious that in some ways Anastasia Cresswell and her sisters represented a new model of young womanhood, for the Cresswells had been encouraged to travel independently around London on their visits to the capital. ${ }^{100}$ This was certainly not lost on the younger girl, who observed that 'She stayed until about 3, then walked off independently to the Edgware Road station on her way to see some friends'. ${ }^{101}$ Participating in a manuscript magazine was clearly illuminating for Knatchbull-Hugessen: it encouraged her to undertake new forms of educational work and enhanced her intellectual confidence. It also shifted her previous reliance upon family structures of sociability, by enhancing her growing sense of a broader girlhood community.

Participation in such pursuits should be understood as part of a broader web of associational and educational activities on the part of young females. Two further, interconnected features of girls' magazine culture will therefore now be considered: correspondence learning and female sociability. Both underline the significance of girls' grass-roots activity for our understanding of the take-up of new educational opportunities. Again, magazine culture, manuscript magazines and their associated activities were entwined in these wider developments.

Gillian Sutherland has observed that historians have constructed 'a false dichotomy between formal and informal ways of learning'. She emphasises the importance of excavating the multiple institutional and associational activities through which educational attainment was achieved in this period. ${ }^{102}$ Correspondence learning exemplifies the point. It was, the Monthly Packet declared, 'the very best preparation for the ordeal of examination; in fact it is a miniature examination of fortnightly recurrences'. ${ }^{103}$ It was also an approach which owed much to the existing 
Page 20 of 27 MAGAZINE CULTURES, GIRLHOOD

practices of girls' self-education outlined above, and, I would suggest, was deeply embedded in magazine culture. Charlotte Yonge's projects are a case in point. In a move which underlines the fluid conception that contemporaries entertained of the various aspects of magazine culture, in I877 Yonge disbanded 'The Barnacle', suggesting that members contribute papers to her commercial magazine, the Monthly Packet, instead. Readers were encouraged to submit pseudonymous essays on a variety of cultural and intellectual topics to its 'Spider's Club'. Yonge now took on the guise of 'Arachne', judging submissions and providing feedback. Although in I868 Yonge had refused to support female colleges, as Susan Walton has recently explained, her views altered during the I870s and by this time she was offering the Monthly Packet as a space for 'distance learning'. ${ }^{104}$

The concept of correspondence learning had underpinned some of the earliest moves in the campaign for women's education. We might consider here the well-known women's rights organisation, the Kensington Society. This was formed in 1865 , with the female education campaigner Emily Davies as secretary, and Charlotte Manning (the first principal of Girton College) as president. Corresponding members were encouraged to join and participants were required to submit written papers on specified topics for discussion. ${ }^{105}$ What is less well known is that, following the society's demise in I868, Emily Davies apparently sought to reanimate its principles by launching a national 'Ladies Improvement Class'. This was to function as a manuscript magazine, with contributors meeting in London annually. ${ }^{106}$ The promotion of correspondence classes became a key objective of the Women's Education Union (WEU), founded in I87I, and by 1877 there was a formal scheme affiliated to Newnham College, Cambridge. ${ }^{107}$ Again, the links with magazine culture were strong. For example, Edith Coleridge, an intimate of 'The Barnacle' manuscript magazine circle (she 20.30 lived with its principal contributor, Christabel Rose Coleridge, and her family for many years), advertised correspondence classes in the WEU's journal from its second year. ${ }^{108}$ Holding a Cambridge Higher certificate herself, she also promoted her correspondence tuition in Greek and Latin in Aunt Judy's Magazine. ${ }^{109}$ This periodical had long encouraged such forms of self-cultivation. It issued monthly questions on a variety of general-knowledge and intellectual topics, providing feedback and prizes for the entries it received. ${ }^{110}$ Similarly, during I880-8I, the Girl's

I04. Walton, 'Spinning the Webs', pp. 278-304.

I05. A. Rosen, 'Emily Davies and the Women's Movement, I862-1867', Journal of British Studies, xix (1979), pp. 107-8.

I06. 'On Dits and Facts of the Month', Ladies' Treasury, i Dec. 1868, p. 9I.

107. Monthly Packet, no. I35, I Mar. 1877, p. 288.

108. Journal of the Women's Education Union, no. 24, is Dec. 1874, p. 182.

I09. Aunt Judy's Magazine, new ser., ii, no. 2I (1883), p. v. Edith Coleridge was the daughter of the literary figure, Sara Coleridge: Memoirs and Letters of Sara Coleridge, ed. Edith Coleridge (London, 1875).

IIo. See, for example, Aunt Judy's Magazine, xv, no. 129 (I877), p. I84. 
Own Paper consistently publicised the available formal correspondence schemes as the best means to prepare for examinations, even stating that 'for all our correspondents we should advise a four months' course of instruction by correspondence'. ${ }^{111}$ It was a mode of education which tessellated well with existing girlhood practices of circulating written work via the postal system for manuscript magazines and other essayled societies - a factor which may well help to explain the appeal and success of these courses.

In I89I, Eva Knatchbull-Hugessen published a story in the Monthly Packet which drew closely upon her experiences during this period. Set in I880, the protagonist was a I7-year-old Kentish woman, who wished to edit a family-based manuscript newspaper, and whose 'great object was to get to one of those places for women at Cambridge or Oxford where they have examinations and so on'. ${ }^{112}$ In fact, KnatchbullHugessen's girlhood biography exemplified the many ways in which female correspondence courses, examinations and magazine culture were intertwined in both practice and imagination. In I880, she and her cousin Mary Dimsdale (1863-1906) embarked on their own version of a correspondence course, agreeing to write to one another once a week on the subject of Roman history. ${ }^{113}$ The teenagers' decision to follow their own correspondence course followed a visit by Dimsdale to Knatchbull-Hugessen's family home in Smeeth, during which the two young women embarked upon an intensive programme of reading, notetaking, questions and abstracts. In their correspondence they set each other weekly questions which they had to mark and return. These study techniques followed closely the advice given in girls' magazines for those approaching the local Cambridge Exams. ${ }^{114}$

The close relationship between girlhood sociability, magazine culture and educational advancement continued when, later that year, Knatchbull-Hugessen, her sister Kate and their mother Anna departed for the island of Madeira for seven months, apparently for the sake of the latter's health. Here, Eva made an effort to develop an educational alliance with a group of young British women resident

III. 'Answers to Correspondents', Girl's Own Paper, no. 76, II June I88I, p. 59I. For further examples, see Girl's Own Paper, no. 45, 6 Nov. I88o, p. 96; no. 26, 26 June I880, p. 415; no. 80, 9 July I88I, p. 643; 'Instruction by Correspondence', no. 57, 29 Jan. I88I, pp. 274-5; 'Just Out', no. 88 , 3 Sept. I88I, p. 775. Parents, too, were increasingly turning to correspondence communities for educational programmes: C. de Bellaigue, 'Charlotte Mason, Home Education and the Parents' National Educational Union in the Late Nineteenth Century', Oxford Review of Education, xli (20I5), pp. 50I-I7.

II2. 'Smite-Them-Hip-and-Thigh', Monthly Packet, no. IO, I Oct. I89I, pp. 386-4I3.

II3. Mary Monica Dimsdale (1863-1906) was the daughter of Cecilia Dimsdale, née Southwell. Cecilia was Eva Knatchbull-Hugessen's maternal aunt. Dimsdale (one of eight children, from Essendon in Hertfordshire) came from a family with more progressive views on the woman question than those of Edward Knatchbull-Hugessen. Mary's father, Robert, tabled motions for female suffrage: 'Record of Events', Englishwoman's Review, I5 June I888, p. 274.

II4. Kent Archives and Local History Centre, U951.F30.4, Knatchbull-Hugessen Diary, (June I880-June I88I), 9 Oct. 1880. See also 2I, 22, 27 and 29 Sept., and I, 23, 25 and 30 Oct. I880. 
Page 22 of 27 MAGAZINE CULTURES, GIRLHOOD

on the island. Of particular importance was her friendship with Dora ('Dolly') and especially Susan ('Suzy') Hinton, sisters whose father, William, was the island's leading businessman. At their first meeting, Knatchbull-Hugessen found that a shared admiration for the works of Charlotte Yonge and Aunt Judy's Magazine created a sense of immediate connection. ${ }^{115}$ As a recent scholar of youth literature has observed, common literary knowledge could act as a springboard for the young in constructing their own networks. ${ }^{116}$ Knatchbull-Hugessen soon discovered that Suzy and Dolly, along with an older sister and a small group of other women, were studying Latin on the island with a former Eton tutor, William Johnson Cory, who was interested in female educational advancement. Following a lengthy argument, Knatchbull-Hugessen persuaded her reluctant mother that she should join the classes, emphasising the isolation of solitary study: 'I wound up with a piteous appeal, it was so hard working on year after year by myself'. ${ }^{117}$ In the event, she attended also the additional, more advanced tutorials which Suzy had been receiving from Cory, the two girls meeting up almost daily to work together. ${ }^{118}$

22.20 These months formed an intense period of stimulating girlhood sociability and study. In April I88I, as Knatchbull-Hugessen contemplated the coming transition back to England and a 'long quiet summer at home', she decided that she would join an educational society for young women on her return. ${ }^{119}$ This was a move inspired 22.25 by learning that Evy Leeke, another of the circle in Madeira, belonged to a reading society. These societies typically used the periodical press as their point of initial contact and were very similar to the magazine society to which Knatchbull-Hugessen had previously belonged. ${ }^{120}$ As Knatchbull-Hugessen explained in her diary, 'You have to read for 22.30 five hours a week ... and if you go in for a prize, you can settle on a particular course which you can choose yourself'. Such activities, like the manuscript magazine, could constitute a long-distance replacement for intellectual sociability. ${ }^{121}$ The experiment of classics tuition on Madeira also somewhat reconciled Anna Knatchbull-Hugessen to her daughter's ambitions, and she acceded to Eva's request that she might continue her education with a tutor on a correspondence basis (although Eva regretted that the arrangement was for her to study with a former Eton

II5. Knatchbull-Hugessen Diary, 2I Jan. I88I.

II6. B. Rouleau, "In Praise of Trash": Series Fiction Fan Mail and the Challenges of Children's

Devotion', Journal of the History of Childhood and Youth, ix (2016), pp. 403-23.

II7. Knatchbull-Hugessen Diary, 2I Jan. I88I.

II8. Knatchbull-Hugessen Diary, I7 May I88I.

II9. Knatchbull-Hugessen Diary, 2 Apr. I88I.

I20. For further examples of such societies and their rules see Caulfield, Directory of Girls' Societies, pp. 38-58.

I2I. Knatchbull-Hugessen Diary, 2 Apr. I88I. 
COMMUNITIES AND EDUCATIONAL REFORM Page 23 of 27

tutor of her brother's, rather than participating in one of the established women's correspondence programmes). ${ }^{122}$

\section{VI}

The intersecting opportunities that Knatchbull-Hugessen seized in relation to magazine culture, female educational sociability and correspondence learning had striking results. In I883, she passed the Higher Local Examination and went up to Newham College, Cambridge. Periodical culture, female correspondence and practices of self-culture thereafter remained central to her career. Indeed, as recent research has established, extra-curricular forms of collaborative study formed an important feature of the communities of early female colleges. This included the composition of amateur magazines to share exam tips and study methods. ${ }^{123}$ Knatchbull-Hugessen co-edited the Newnham Chronicle and also authored a set of 'Suggestions to Classical Students' for freshers. ${ }^{124}$ After Newnham, she published three widely publicised articles defending female higher education and explaining life at the college, one of which appeared in Atalanta. ${ }^{125}$ In 1887 , Knatchbull-Hugessen was delighted to be commissioned by Charlotte Yonge to write a series of literature papers for the Monthly Packet to help prepare young women for the Cambridge Higher Local Examinations. ${ }^{126}$ She also set essay questions arising from the papers for readers. These were marked by Bessie Mackenzie, a friend from Newnham, and the subsequent results were published in the Monthly Packet. $^{127}$

While we now have a keen sense of the intricacies of women's professional authorship, the experiences of Knatchbull-Hugessen and others like her highlight the significance and achievements of amateur publication at specific life stages. ${ }^{128}$ Sally Mitchell and

I22. Cambridge, King's College, OB/I/917/C, Anna Knatchbull-Hugessen to Oscar Browning, 24 Jan. [n.y.]); King's College, OB/I/9/918/A, letters from Eva Knatchbull-Hugessen to Oscar Browning, I88I-3. Like Cory, Browning left his position as an Eton tutor over allegations concerning sexual impropriety with pupils. He developed a reputation as an educational reformer, sympathetic to female students. P. Hirsch and M. McBeth, Teacher Training at Cambridge: The Initiatives of Oscar Browning and Elizabeth Hughes (London, 2004), pt. I.

I23. Lamberton, 'A Revelation and a Delight'.

I24. Knatchbull-Hugessen Diary, 27 Jan. and I June I886.

I25. Eva Knatchbull-Hugessen, 'Newnham College from Within', Nineteenth Century, no. I24, June 1887, pp. 843-56, 'The Higher Education of Women', National Review, vol. xiii, no. 73, Mar. I889, pp. 33-44, and 'Oxford and Cambridge Colleges for Women', Atalanta, no. 3I, I Apr. I890, pp. 42I-3. 'Newnham College from Within' was originally to be published in the Monthly Packet, but Knatchbull-Hugessen agreed in consultation with Charlotte Yonge that it would be better to select a magazine with a wider readership: Knatchbull-Hugessen Diary, 20 Oct. I886.

I26. Kent Archives and Local History Centre, U95I.F.30.8, Knatchbull-Hugessen Diary (May I887-May I889), I4 Dec. I887.

I27. 'Notices to Correspondents', Monthly Packet, no. 89, i May I888, p. 499. KnatchbullHugessen's essays appeared monthly from July I888 to June I889.

I28. See L.H. Peterson, Becoming a Woman of Letters: Myths of Authorship and Facts of the Victorian Market (Princeton, NJ, 2009). 


\section{Page 24 of 27 MAGAZINE CULTURES, GIRLHOOD}

Beth Rodgers have pointed to the continuing importance into the early twentieth century of writing as a profession for women of the middle classes. Gaining a foothold in the world of print through essay competitions could be an important entry point. ${ }^{129}$ The phenomenon of manuscript magazines is intertwined with this history, indicating that their significance to contemporaries included the wider opportunities they might herald and the training they brought. Certainly, many of those who contributed to manuscript magazines entertained hopes that their work would eventually appear in print. Jane Panton recalled that nearly all the poems she contributed to a manuscript magazine were published subsequently in well-known periodicals. ${ }^{130}$ This was clearly the rationale behind one manuscript magazine advertised in Aunt Judy's Magazine, optimistically entitled 'The Dawn of Literary Fame'. ${ }^{131}$ Anastasia Cresswell had plans to publish a selection of the material which appeared in her manuscript magazine and advised KnatchbullHugessen that three of her pieces would be included in such a selection. Whether or not this transpired has proved impossible to determine. However, Knatchbull-Hugessen was delighted when 24.20 she secured a contract with Routledge to publish one of the pieces originally written for 'Our Monthly Magazine', 'Judy' (a story about a 9-year-old girl canvassing at a general election), plus one other composed during the I880-8I period, 'Pirouetta'. Both were published in the Routledge children's periodical Little Wideawake in $24.25 \quad$ I882. ${ }^{132}$ In I885, Knatchbull-Hugessen had these two stories specially bound for Helen Gladstone, the Vice Principal of Newnham College, as a birthday present. ${ }^{133}$ This gift seems symbolic of the connections Knatchbull-Hugessen made between her involvement in magazine culture, girlhood support, and her later college study. 24.30 On leaving college, she was successful in publishing a number of stories in children's magazines, the proceeds often going to support Newnham College funds. ${ }^{134}$

The contrasting afterlives of the contributors to 'Our Monthly Magazine' underline the uneven and diverse experiences of this 24.35 pioneering generation. Both Anastasia and Beatrix Cresswell wrote regularly for the local press in the early i88os. Beatrix also went on to become a prolific author, writing on Devonshire and church history as

I29. Rodgers, Adolescent Girlhood, ch. 6; S. Mitchell, 'Career for Girls: Writing Trash',

130. Panton, Leaves From a Life, p. 272.

I3I. Aunt Judy's Magazine, new ser., i, no. I2 (I882), p. 759.

I32. Knatchbull-Hugessen Diary, I2 Oct. I880, I6 Feb. I88I; 'Judy, or Light Blue', Little Wide Awake (1882), pp. 248-55, 282-6, 3II-I8, 340-45; 'Pirouetta: A Comedietta', ibid., pp. 49-64.

I33. Knatchbull-Hugessen Diary, I7, I9 and 2I Aug. I885.

134. See Knatchbull-Hugessen Diary, I4 Feb. I887. Her key works are The Night-Hawkes 
COMMUNITIES AND EDUCATIONAL REFORM Page 25 of 27

well as contributing to various periodicals, including Yonge's Monthly Packet. ${ }^{135}$ The longer legacy of their years of girlhood authorship was complicated. In the I870s, Beatrix had considered entering the local examinations and there was some discussion about the possibility of her attending Girton College. ${ }^{136}$ In the event, in the year when Knatchbull-Hugessen went up to Cambridge, Beatrix and Anastasia undertook a voyage to Canada for a prolonged visit. ${ }^{137}$ Subsequently, Beatrix travelled extensively across Europe with two literary sisters, Lucy and Mary Anne Gardiner of Denbury Hall, and later moved back home to care for her mother. This was a decision which she believed to have had a negative impact upon her literary career. Nonetheless, she too extolled some of the new freedoms open to this generation, which in her case involved that emblematic activity of the new woman, cycling. ${ }^{138}$ As she later wrote, 'Emancipation came with the bicycle'. ${ }^{139}$ Anastasia's later life was also shaped by the possibilities open to the 'new woman'. ${ }^{140}$ She ultimately set up a home in Dumfries with her cousin Henrietta, a well-established artist, with whom she had an intimate relationship. Henrietta had herself run a drawing club, advertised in Aunt Judy's Magazine, in the early I880s. ${ }^{141}$ The two women went on to edit a manuscript magazine together, and, in the early twentieth century, they wrote for the women's column of the Glasgow Herald. ${ }^{142}$ As these examples suggest, participation in such activities could produce diverse trajectories. But there is no doubting the significance of the intricate webs of connection between girlhood communities of self-education and raised female aspirations.

It may well be that the I870s and I880s represented the heyday of the juvenile manuscript magazine. The Cresswells believed that 'the cheap newspapers with their prize competitions virtually killed it'. ${ }^{143}$ For a critical period, however, manuscript magazines and other similar societies equipped young girls with a facility for networking, educational support and the formation of a collective identity. This of Miss B. F. Cresswell'.

I36. Cresswell's godmother was hoping she would go to Girton, but her father was opposed. Cresswell later claimed she had not desired to attend college: Cresswell, 'Autobiographical Notes'.

137. Devon Heritage Centre, MSX 920/CRE, Beatrix Cresswell, journal of a voyage to Canada.

I38. K. McCrone, Playing the Game and the Physical Emancipation of English Women, I8701914 (Lexington, KY, 1988), pp. 177-84.

139. Cresswell, 'Autobiographical Notes'. Cresswell became a contributor to the specialist cycling press, such as Cycling, I897-1900.

I40. The literature on the 'new woman' and its complexities is extensive. Few fitted the discursive category neatly. See, especially, G. Sutherland, In Search of the New Woman: MiddleClass Women and Work in Britain, I870-1914 (Cambridge, 2015); P. Marks, Bicycles, Bangs and Bloomers: The New Woman in the Popular Press (Lexington, KY, 1990); M.E. Tusan, 'Inventing the New Woman: Print Culture and Identity Politics during the Fin-de-Siècle', Victorian Periodicals Review, xxxi (1998), pp. I69-82.

I4I. Aunt Judy's Magazine, new ser., i, no. Io (I882), p. 637.

I42. Hodge, Cresswells, p. 22I.

I43. Cresswell, 'Autobiographical Notes'. 


\section{Page 26 of 27 MAGAZINE CULTURES, GIRLHOOD}

came at a time when educational reforms and burgeoning opportunities in periodical authorship, work and travel invited young females to expand their horizons and expectations; but the fulfilment of these developments depended upon a cohort of girls with the confidence to embrace them. Young women's interaction with cultural networks of wide geographic scope appears to have facilitated an emergent sense of 'collective girlhood' for many. This enabled female youth to construct an independent network of like-minded individuals, quite distinct from the usual patterns of sociability which tended to be restricted to those of similar class status. An ability to identify instead as part of a larger constituency of girlhood, and young women's own dynamic activities in creating this, should be seen as part of the grassroots response to the reforms of female education in the I870s and i88os.

There has been much debate in recent studies of childhood and youth over the vexed issue of juvenile agency, including warnings of the dangers of idealising the concept. ${ }^{144}$ The agency that Knatchbull-Hugessen could exercise clearly needs to be understood contextually: her ability to make decisions about her education depended on her elite social positioning and generally supportive family environment. Despite her father's mistrust of female higher education, he was happy to assist in placing her stories for publication; her parents consented, albeit reluctantly, to 26.25 secure tutors for her examinations. ${ }^{145}$ Yet it is her quiet but determined response to the initial manuscript magazine advert-'I decided to join'-which exemplifies the argument advanced in this article. It is symptomatic of the myriad of small, but significant resolutions taken by those Victorian girls and teenagers keen to seize new opportunities. 26.30 Cumulatively, these decisions had far-reaching consequences.

Recent work has emphasised the diversity of intellectual currents underpinning reforms to female education, including the influence of conservative Anglicanism. ${ }^{146}$ Neither Knatchbull-Hugessen nor the Cresswell sisters articulated their aspirations within the context of women's 26.35 rights. Rather, that exemplar of High Church morality, Charlotte Yonge, emerged as a key source of inspiration in their quest for intellectual autonomy. As Midori Yamaguchi has demonstrated, the relationship between Anglicanism and female higher education was rarely straightforward. ${ }^{147}$ Yet for example, Knatchbull-Hugessen Diary, 2I Feb. and 20 Apr. I886.

146. L. Schwartz, 'Feminist Thinking on Education in Victorian England', Oxford Review of Education, xxxvii (201I), pp. 669-82; J. Bush, "Special Strengths for their own Special Duties”: Women, Higher Education and Gender Conservatism in Late Victorian Britain', History of Education, xxxiv (2005), pp. 387-405.

I47. Yamaguchi, Daughters of the Anglican Clergy, ch. 2. 
for a generation of young women whose loyalties were deeply embedded in the hierarchical ties of family, neighbourhood and church, the insistence of those such as Yonge on the Christian appropriateness of girls' self-cultivation provided an accessible starting-point from which to navigate the conflicting range of new messages.

Mitchell's analysis of 'the new girl' supposed it to be a category barely in existence in $188 \mathrm{O}$. The material considered here indicates that a rich subculture of girlhood associational life was already well established by that date. This suggests that the representations of girls discussed in Mitchell's study were not only a reflection of broader social changes, but were actually a response to girls' grass-roots behaviour. To date, much of the history of Victorian girlhood has tended to be written from a top-down perspective, reconstructed through medical or literary texts, or with a focus upon memoirs written in adulthood. ${ }^{148}$ Approaching girlhood culture through girls' own manuscripts and practices has radical implications. It enables us to tease open how girls themselves responded to, and created their own opportunities for, far-reaching educational advancement. 